\title{
Smithsonian looks beyond ousted boss
}

By any standards, it was a controversial reign. It started with an investigation into the purchase of feathers from endangered birds; not what you might expect from a man with ultimate responsibility for one of the world's most prestigious natural history museums. It ended last week amid media claims of lavish expense accounts, including thousands of dollars for the upkeep of a private swimming pool and the cleaning of a chandelier. It is unlikely that many tears were shed at the Smithsonian Institution on 26 March, when officials announced that Larry Small had resigned.

The departure of Small, who has led the 19 museums and 9 research centres that make up the institution since 2000, closes one of the more turbulent periods in the organization's 160 -year history. Yet researchers at the institution say that the problems they face run deeper than those allegedly caused by Small's management approach (see 'A lavish seven years').

For around 15 years, the Smithsonian's core research budgets have eroded, forcing administrators to rely increasingly on outside funds. And although donors can often be persuaded to stump up for glamorous projects such as new exhibitions, finding funds for research costs is much more challenging. As a result, although Small carried out much-needed repairs and launched new museums, he did not stop the slide in funding for research and training. Of the nearly US $\$ 1$ billion he raised in private money, almost all went to infrastructure projects such as new galleries, rather than to research.

"This issue won't go away because Larry has

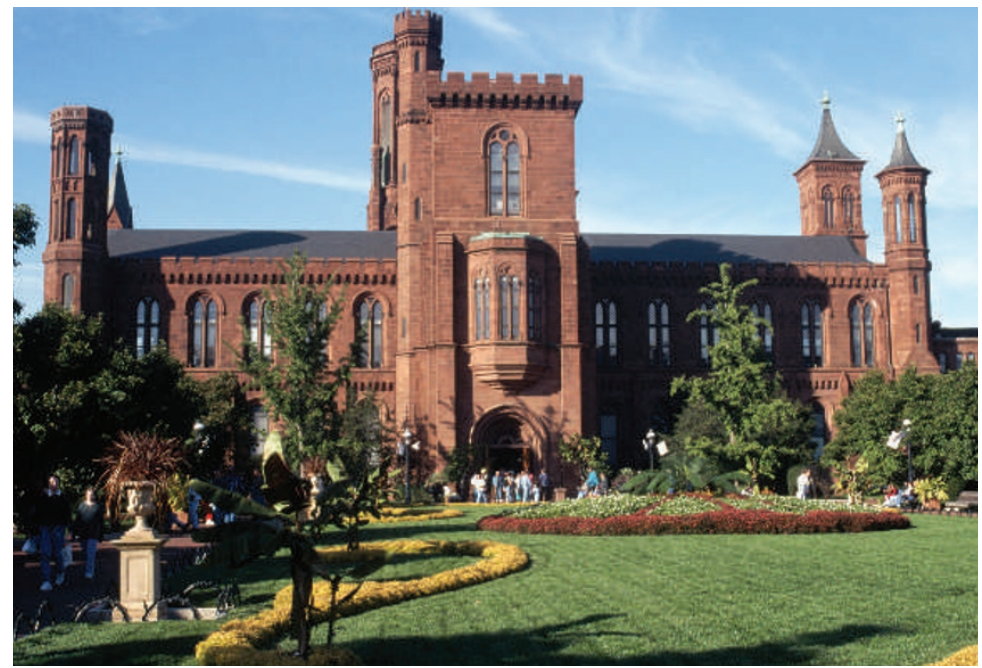

The Smithsonian's core research budgets have been falling for 15 years.

gone," warns Stephen Murray, deputy director for science at the Harvard-Smithsonian Center for Astrophysics in Cambridge, Massachusetts.

Smithsonian officials say that they don't have figures for how much money from the institution's overall budget goes towards science, but research leaders think that the attrition in funding has hit many areas. Researchers from a variety of specialities told Nature that as many as a third of full-time positions have been lost from their departments over the past 15 or so years. Where centres have prospered, it has generally been because they tapped into funding streams that became national priorities, such as money for research on climate change and its effects, or could raise money from philanthropic sources.

\section{A lavish seven years}

Larry Small was always

likely to make waves at the

Smithsonian Institution. As a successful business leader, he brought with him a corporate, goal-orientated attitude that is at odds with the academic freedom that scientists seek.

That approach brought benefits: an ability to raise funds that led to the creation of new museums devoted to American Indians and aerospace, for example. But Small also angered scientists by proposing in 2001 to close two research centres without first running detailed consultations. Opposition from staff and Congress forced him to back-track. Earlier that year, Small had been investigated for his collection of Latin American masks, head-dresses and costumes. He was eventually prosecuted in 2004 for purchasing artefacts that contained feathers from endangered birds and served 100 hours' community service. But it was Small's expense account that caused most anger in Congress and eventually forced him out. He used his Washington home for Smithsonian functions and allegedly received more than $\$ 1$ million in housing allowances during his seven years in charge, according to The Washington Post. The newspaper claims that invoices included $\$ 273,000$ in housekeeping services, $\$ 2,535$ to clean a chandelier and $\$ 12,000$ for the upkeep of his swimming pool. The expenses were permitted under Smithsonian policy, although an internal institution report, issued in January, had noted that some of Small's expenses "might be considered lavish or extravagant". When he quit last week, Small was earning more than $\$ 915,000$.
Although researchers think that a mix of funding streams is a good thing, they don't want this strategy to replace core federal funding. For example, the Smithsonian's centres hold records on forest growth and bird migration and behaviour that span 25 years. Such long-term data - one of the institution's great strengths - are hard to maintain with agency grants, which generally run for only three to five years.

"The value of long-term monitoring depends on its continuity," says Ira Rubinoff, acting under-secretary for science at the institution. Rubinoff, has secured a private donation to maintain the forest work, but only for five more years. Like other researchers, he says that he now needs to devote more time to fundraising.

With this history in mind, Smithsonian scientists say that beefing up core funding should be a priority for the next director. That feeling is shared by the new acting head, Cristián Samper, director of the National Museum of Natural History in Washington DC, where core funding has decreased by around 3\% a year over the past eight years. Samper hopes that the trend can be reversed by improving the advertising of Smithsonian research to Congress and the public, in part by getting more of that science into the exhibitions that the Smithsonian runs.

Samper is one of many names being suggested in discussions over Small's successor, but he comments only that he would be happy to remain as head permanently, or to go back to running the national museum. The search is being run by members of the museum's Board of Regents and is expected to take about a year.

Jim Giles 